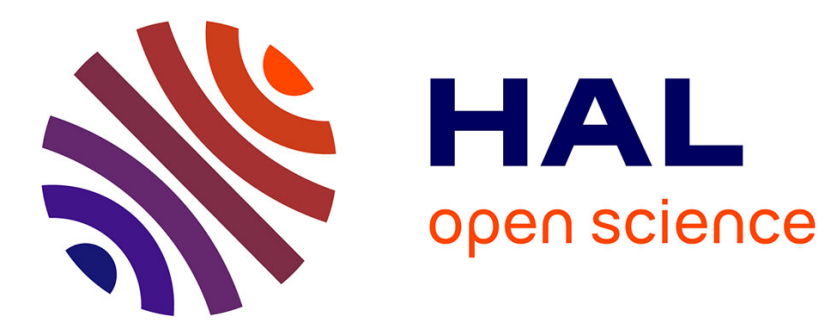

\title{
Transcriptional down-regulation of Bcl-2 by vinorelbine: identification of a novel binding site of p53 on Bcl-2 promoter
}

Véronique Bourgarel-Rey, Amandine Savry, Guoqiang Hua, Manon Carré, Céline Bressin, Christine Chacon, Jean Imbert, Diane Braguer, Yves Barra

\section{To cite this version:}

Véronique Bourgarel-Rey, Amandine Savry, Guoqiang Hua, Manon Carré, Céline Bressin, et al.. Transcriptional down-regulation of Bcl-2 by vinorelbine: identification of a novel binding site of p53 on Bcl-2 promoter. Biochemical Pharmacology, 2009, 78 (9), pp.1148. 10.1016/j.bcp.2009.06.025 . hal-00519080

\section{HAL Id: hal-00519080 \\ https://hal.science/hal-00519080}

Submitted on 18 Sep 2010

HAL is a multi-disciplinary open access archive for the deposit and dissemination of scientific research documents, whether they are published or not. The documents may come from teaching and research institutions in France or abroad, or from public or private research centers.
L'archive ouverte pluridisciplinaire HAL, est destinée au dépôt et à la diffusion de documents scientifiques de niveau recherche, publiés ou non, émanant des établissements d'enseignement et de recherche français ou étrangers, des laboratoires publics ou privés. 


\section{Accepted Manuscript}

Title: Transcriptional down-regulation of Bcl-2 by vinorelbine: identification of a novel binding site of $\mathrm{p} 53$ on Bcl-2 promoter

Authors: Véronique Bourgarel-Rey, Amandine Savry, Guoqiang Hua, Manon Carré, Céline Bressin, Christine Chacon, Jean Imbert, Diane Braguer, Yves Barra

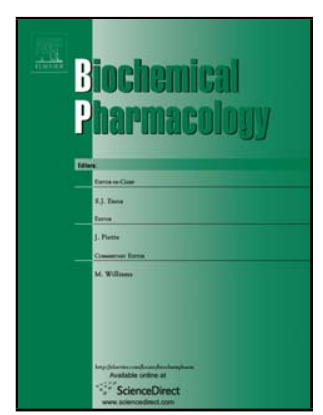

PII: S0006-2952(09)00494-8

DOI: doi:10.1016/j.bcp.2009.06.025

Reference: BCP 10234

To appear in: $\quad B C P$

Received date: $\quad 30-3-2009$

Revised date: $\quad$ 12-6-2009

Accepted date: $\quad$ 16-6-2009

Please cite this article as: Bourgarel-Rey V, Savry A, Hua G, Carré M, Bressin C, Chacon C, Imbert J, Braguer D, Barra Y, Transcriptional down-regulation of Bcl-2 by vinorelbine: identification of a novel binding site of $\mathrm{p} 53$ on Bcl-2 promoter, Biochemical Pharmacology (2008), doi:10.1016/j.bcp.2009.06.025

This is a PDF file of an unedited manuscript that has been accepted for publication. As a service to our customers we are providing this early version of the manuscript. The manuscript will undergo copyediting, typesetting, and review of the resulting proof before it is published in its final form. Please note that during the production process errors may be discovered which could affect the content, and all legal disclaimers that apply to the journal pertain. 


\section{Transcriptional down-regulation of $\mathrm{Bcl}-2$ by vinorelbine: identification of a novel}

\section{binding site of p53 on Bcl-2 promoter}

Véronique Bourgarel-Rey ${ }^{\mathrm{a}^{*}}$, Amandine Savry ${ }^{\mathrm{a}}$, Guoqiang Hua ${ }^{\mathrm{b}}$, Manon Carré ${ }^{\mathrm{a}}$, Céline

Bressin $^{\mathrm{a}}$, Christine Chacon ${ }^{\mathrm{a}}$, Jean Imbert ${ }^{\mathrm{b}}$, Diane Braguer ${ }^{\mathrm{a}}$, and Yves Barra ${ }^{\mathrm{c}}$.

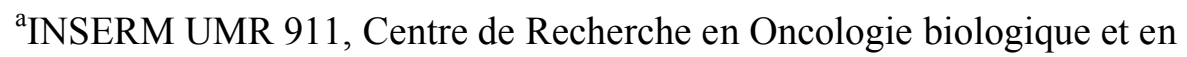

Oncopharmacologie; Aix-Marseille Université ; Faculté de Pharmacie, 27 Boulevard Jean

Moulin, 13385 Marseille Cedex 5, France

${ }^{\mathrm{b}}$ U928 INSERM, TAGC, Université de la Méditerranée, 163, Avenue de Luminy, 13288

Marseille cedex 09, France

'UMR INSERM 476/INRA 1260, Université de la Méditerranée, 27 Bd Jean Moulin, 13385

Marseille Cedex 05, France

*Corresponding author

\section{Running title: Implication of p53 in decrease of Bcl-2 by vinorelbine}

Nonstandard Abbreviations: Microtubule-Targeting Agents (MTAs), vinorelbine (VRL),

Chromatin ImmunoPrecipitation (ChIP)

Keywords: vinorelbine, Bcl-2 promoter, p53, apoptosis

Correspondence: Véronique Bourgarel-Rey, UMR INSERM 911, Faculté de pharmacie, 27

BD Jean Moulin, 13385 Marseille cedex 5, France.

Tel: 00334918356 03, Fax: 0033491835594

E-mail: veronique.rey@univmed.fr,

Disclosure statement: The authors have nothing to disclose 


\section{Abstract}

The Bcl-2 family contains a panel of proteins which are conserved regulators of apoptosis in mammalian cells, like the anti-apoptotic protein Bcl-2. According to its significant role in altering susceptibility to apoptosis, the deciphering of the mechanism of Bcl-2 expression modulation may be crucial for identifying therapeutics strategies for cancer. Treatment with microtubule -targeting agents, including taxanes and Vinca alkaloids, generally leads to a decrease in Bcl-2 intracellular amounts. Whereas the interest for these chemotherapeutics is accompanied by advances in the fundamental understanding of their anticancer properties, the molecular mechanism underlying changes in $\mathrm{Bcl} 2$ expression remains poorly understood. We report here that $\mathrm{p} 53$ contributes to vinorelbine-induced $\mathrm{Bcl}-2$ down-regulation. Indeed, the decrease in Bcl-2 protein levels observed during vinorelbineinduced apoptosis was correlated to the decrease in mRNA levels, as a result of the inhibition of Bcl-2 transcription and promoter activity. In this context, we evaluated p53 contribution in the Bcl-2 transcriptional down-regulation. We identified, by chromatin immunoprecipitation, a novel p53 binding site in the Bcl-2 promoter, within a region upstream $\mathrm{P}_{1}$ promoter. We showed that vinorelbine treatment increased this interaction in A549 cells. This work strengthens the links between p53 and Bcl-2 at a transcriptional level, upon microtubuletargeting agent treatment. Our study also provides answers that will be useful to assess microtubule-targeting agents' mechanism of action and that may help to better understand and increase their effectiveness. 


\section{Introduction}

Apoptosis is a tightly regulated process that has important implications during physiological development and in disease progression. Indeed, a disruption of the normal apoptotic process is implicated in a variety of human disorders, including cancer [1]. Importance of apoptosis induction in cancer therapy is still growing and the ongoing discovery of numerous apoptosis-regulating proteins provides new potential targets for molecular cancer therapy.

The Bcl-2 protein is a highly conserved member of the Bcl-2 family and constitutes an important regulator of apoptosis [2]. Bcl-2 plays a major role in oncology, its overexpression is common in many types of cancer, and it is suggested to contribute to an increased resistance to chemotherapy and radiotherapy [3]. The common explanation of how Bcl-2 inhibits apoptosis is focused on the preservation of the mitochondrial membrane integrity and the prevention of the release of several apoptogenic molecules from mitochondria [2]. This is necessary for the activation of caspases, and it is generally considered as sufficient to induce apoptosis [4].

Microtubule-Targeting Agents (MTAs) are used in clinical therapies for various types of tumours. The MTA family contains compounds able to inhibit microtubule polymerisation (Vinca alkaloids) whereas others stabilise microtubules (Taxanes and Epothilones). Vinorelbine (VRL) is a semi synthetic Vinca alkaloid derivative that is widely used in the treatment of metastatic breast and non-small-cell lung malignancies [5]. It depolymerises the microtubule network and leads to apoptosis after cell cycle arrest. Like other MTAs, it activates the intrinsic mitochondrial apoptotic pathway [6-8].

Bcl-2 expression can be modulated at both transcriptional and post-transcriptional levels. Two promoters, $\mathrm{P}_{1}$ and $\mathrm{P}_{2}$, control Bcl-2 gene transcription [9]. The $\mathrm{P}_{1}$ major 
transcriptional start site (TSS) is located 715 bp upstream of the Bcl-2 translational start site, whereas the start sites of the $3^{\prime}$ promoter $\left(\mathrm{P}_{2}\right)$ are located $1.3 \mathrm{~kb}$ downstream of the $\mathrm{P}_{1}$ promoter. Only the $\mathrm{P}_{2}$ promoter has canonical TATA and CAAT boxes. Several transcription factors are known to be involved in the positive regulation of Bcl-2 transcription, including cAMP responsive element binding protein (CREBP) [10] and NFкB [11]. Besides these positive transcriptional regulators, a number of negative regulatory sites have been described, including $\pi 1$ binding sites in pre-B cells [12], WT1 binding sites [13], and p53 binding sites. Indeed, it has been shown that a $195 \mathrm{bp}$ region containing the TATA sequence can mediate p53-dependent repression through the PNRE (p53 negative responsive element)[14, 15]. Additionally, the bcl-2 promoter region located between $\mathrm{P}_{1}$ and $\mathrm{P}_{2}$ displays a promoter activity that is also suppressed by $\mathrm{p} 53$ [16]. Besides its transcriptional regulation, $\mathrm{Bcl}-2$ is post-transcriptionally modified by phosphorylation at putative mitogen-activated protein kinase sites which leads to ubiquitination, proteasome-dependent degradation, and caspasedependent cleavage, resulting in the loss of anti-apoptotic activity [17].

Increasing evidence supports the modulation of $\mathrm{Bcl}-2$ expression is related to chemotherapy response including MTAs [18-19]. Thus, its value as potent therapeutic target is currently increasing. We had previously demonstrated that MTAs induced Bcl-2 phosphorylation or Bcl-2 protein decrease, and participating in cell sensitivity to treatment by promoting apoptosis [7, 20-21]. Paradoxically, Bcl-2 down-regulation has been associated with resistance to paclitaxel and vinflunine [22-23], suggesting that a minimal Bcl-2 level would be necessary for MTA sensitivity. Hence, it appears essential to gain further insight into Bcl-2 regulation by Vinca alkaloids. We focused here on the molecular mechanism underlying the Bcl-2 decrease induced by VRL. We found that this decrease involves a transcriptional level requiring the wild-type apoptotic protein p53. P53 mediates Bcl-2 downregulation through its binding to a consensus binding site $1 \mathrm{~kb}$ upstream of $\mathrm{Bcl}-2 \mathrm{P}_{1}$ promoter. 


\section{Materials and methods}

\subsection{Cell lines and reagents}

A549 (wild-type p53) human non-small-cell lung carcinoma cells, MCF7 (wild-type p53) and SKBR3 (inactive mutant of p53) human breast cancer cells were used. These cells were routinely cultured in RPMI medium (A549) or DMEM (MCF7 and SKBR3) supplemented with $10 \%$ foetal bovine serum, $2 \%$ L-glutamine, and $1 \%$ penicillin and streptomycin, at $37^{\circ} \mathrm{C}$ with $5 \% \mathrm{CO}_{2}$.

Stock solution of Vinorelbine (Sigma, Steinheim, Germany) was conserved at $4{ }^{\circ} \mathrm{C}$ and working dilutions in medium were kept frozen.

\subsection{Cytotoxicity Assay:}

Growth inhibition of different cell lines were studied after a 72-h treatment with different agents, VRL and doxorubicine, by using the MTT cell proliferation assay as previously described (Pourroy et al., 2004). Doses used in experiment are noticed as IC50, IC70 or IC80 in each cell line.

\subsection{DAPI staining}

A549 cells were grown on 8-well plates (Labteck, Naperville, IL) and incubated with 10 and $100 \mathrm{nM}$ VRL for $72 \mathrm{~h}$. They were then fixed with $3.7 \%$ formaldehyde and incubated with DAPI (Sigma) to stain the nuclei [24]. Cells were observed under a Leica DM-IRBE microscope coupled with a digital camera (coolsnapFX CCD camera; Princeton Instruments). Four hundred cells were analyzed using Metamorph software.

\subsection{Quantitative expression of Bcl-2 mRNA by real time qRT-PCR}

Total cellular RNA was extracted with the nucleospin RNA II kit in accordance with the manufacturer's instructions (Macherey-Nagel, Hoerdt, France) and $1 \mu \mathrm{g}$ of total RNA was used for reverse transcription with random primers. Bcl-2 expression in relation to $\beta 2$ microglobulin $(\beta 2 \mathrm{~m})$ expression (internal standard) was determined using the LightCycler 
System and the FastStart DNA master SYBRGreen I kit (Roche Diagnostics, Manheim, Germany). $\mathrm{MgCl}_{2}$ concentration was set at $5 \mathrm{mM}$ and the primers used $(0.25 \mu \mathrm{M})$ for $\mathrm{Bcl}-2$ and $\beta 2 \mathrm{~m}$ were described in Table 1.

Cycling conditions were as follows: 10 -min denaturation step at $95^{\circ} \mathrm{C}$ followed by 45 cycles with $10 \mathrm{~s}$ denaturation at $95^{\circ} \mathrm{C}, 8 \mathrm{~s}$ primers annealing at $60^{\circ} \mathrm{C}$, and $6 \mathrm{~s}$ of elongation at $72^{\circ} \mathrm{C}$. The LightCycler was programmed to carry out a melting cycle to verify the specificity of the amplified products. Melting curves and quantitations were analysed using LightCycler and Rel Quant softwares, respectively.

\subsection{Western blotting}

After treatment, the cells were washed with PBS and lysed as previously described[7]. The membranes were then probed with either an anti-poly(ADP-ribose) polymerase (PARP) (Zymed, San Francisco, CA) (1:500) or anti-Bcl-2 (Dako) (1:100), anti-p53 (Dako, Glostrup,

Denmark) (1:100), or anti-p21 ${ }^{\mathrm{WAF} 1}$ (Oncogene, Darmstadt, Germany) (1:100) mouse monoclonal antibodies. Then blots were labeled with peroxidase conjugated secondary antimouse antibody (Jackson Immunoresearch, Baltimore, MD) (1:3000). Visualisation was performed by chemiluminescence. Hybridization with anti-actin mouse monoclonal antibody (1:1000, Sigma) was used to control equal loading.

\subsection{Plasmid constructs and transfection}

The Bcl-2 full-length promoter-luciferase construct (pGL3-Bcl-2) was kindly provided by Dr Richard J Bold [25]. Cells seeded into 12-well plates and grown to 90-95\% confluence were transiently transfected with $1.6 \mu \mathrm{g}$ DNA of this Bcl-2 promoter luciferase construct using Lipofectamine 2000 reagent, as suggested by the manufacturer (Invitrogen Life Technologies, Carlsbad, CA). After 5h of transfection, cells were washed and a fresh medium or medium including 10 or $100 \mathrm{nM}$ VRL was added. Cells were harvested after $4 \mathrm{~h}, 8 \mathrm{~h}, 12 \mathrm{~h}, 18 \mathrm{~h}$ and $24 \mathrm{~h}$ post-treatment respectively. Luciferase assays were performed with the Bcl-2 transfected 
cells lysate, using the Luciferase Assay System kit (Promega, Madison, WI). Luciferase activity was evaluated using a luminometer. The transfection efficiency between dishes was verified by transfecting cells with $\mathrm{pCMV} / \beta$-gal. $\beta$-Galactosidase activity was evaluated by spectrofluorometry as described previously (Bourgarel-Rey et al., 2000). All transfections were performed at least in triplicate.

\subsection{Evaluation of hnRNA levels}

RT-PCR was conducted to amplify a region of Bcl-2 heterogeneous nuclear RNA (hnRNA) transcript. Total RNA extraction and reverse transcription were carried out as previously described for qRT-PCR. The RNA extraction includes a DNAse treatment to degrade the genomic DNA. For the PCR reaction, the primers were chosen from intronic regions to amplify a 212 bp sequence specific for a primary unprocessed transcript (Table 1). Absence of amplification products with non-reverse transcribed RNA was used as a control to verify the absence of potential contamination by genomic DNA (data not shown). We then amplified Bcl-2 hnRNA and $\beta_{2} \mathrm{~m}$. The reaction conditions included a denaturation step at $93^{\circ} \mathrm{C}$ for $4 \mathrm{~min}$, followed by 25 (for $\beta 2 \mathrm{~m}$ ) and 34 cycles (for Bcl-2) of denaturation at $93^{\circ} \mathrm{C}$ for $30 \mathrm{~s}$, annealing at $55^{\circ} \mathrm{C}$ for $30 \mathrm{~s}$, and elongation at $72^{\circ} \mathrm{C}, 30 \mathrm{~s}$. We determined that the amplification fell within the linear range with 25 cycles for $\beta 2 \mathrm{~m}$ and 34 cycles for Bcl-2. Amplified products were separated by electrophoresis on a $2 \%$ agarose gel. DNA bands were visualized by ethidium bromide staining, and the image was then digitized. The level in Bcl-2 hnRNA was normalized to $\beta 2 \mathrm{~m}$ transcript. The percentages of variation of $\mathrm{Bcl}-2 \mathrm{hnRNA}$ reported in the text were the mean values of three experiments.

\subsection{Chromatin ImmunoPrecipitation Assay}

The ChIP assay was performed using the EZ ChIP kit according to the manufacturer's directions (Upsate, Lakeplacid, NY). After 12h treatment with $10 \mathrm{nM} \mathrm{NVB,} 2.5 \times 10^{6}$ cells were harvested, crosslinked with $1 \%$ formaldehyde and the reaction was quenched by glycine 
$125 \mathrm{mM}$. Cells were lyzed and sonicated to generate chromatin fragments between 200 and $1000 \mathrm{bp}$. Sheared chromatin fractions were incubated overnight with anti-p53 antibody (p53 (DO-1): sc-126, Santa Cruz Biotechnology, Santa Cruz, CA) on rotating device at $4^{\circ} \mathrm{C}$. Immunocomplexes were then washed and eluted with elution buffer. The eluates and the input sample ( $1 \%$ of the amount used in the IP procedure) were reverse-crosslinked by incubating at $65^{\circ} \mathrm{C}$ overnight in presence of $0.2 \mathrm{M} \mathrm{NaCl}$. After Rnase and proteinase $\mathrm{K}$ digestion, the DNA fragments were extracted using phenol-chloroform and purified using Qiagen PCR purification kit. Presence of selected DNA sequences was assessed by quantitative PCR. Sequences of primers are given in Table 1.

\subsection{Statistical analysis}

Each experiment was performed at least in triplicate. Statistical significance was tested using the student's T test for comparisons between the means, and differences between two conditions were retained for $\mathrm{p}<0.05$. 


\section{Results}

\subsection{Apoptosis induction by Vinorelbine is correlated with Bcl-2 down-regulation}

We first determined the IC50 value, i.e 7nM, of VRL in A549 cells by MTT assay (Fig.1A). As evaluated by DAPI staining after a $72 \mathrm{~h}$-treatment, VRL induced apoptosis in A549 cells, in a concentration-dependent manner: $7 \pm 3 \%, 21 \pm 1 \%$ and $27 \pm 4 \%(\mathrm{p}<0.05)$ with 10, 50 and $100 \mathrm{nM}$, respectively (Fig. 1B). Apoptosis induction was further confirmed by PARP cleavage (116 kDa to $89 \mathrm{kDa}$ fragment) after VRL treatment (Fig. 1C).

Bcl-2 expression was then determined in these apoptotic conditions. VRL treatment (48h) resulted in a significant decrease of Bcl-2 protein from $37 \pm 2 \%$ to $60 \pm 4 \%$ with $10 \mathrm{nM}$ (IC70) and $100 \mathrm{nM}$ VRL, respectively (Fig. 2A). Bcl-2 down-regulation was maintained until apoptosis completion (72h), and reached $69 \pm 5 \%$ with $100 \mathrm{nM}$ VRL. This result was confirmed in breast cancer cells MCF-7, since 50nM VRL (IC80) decreased Bcl-2 protein at $48 \mathrm{~h}$ by $50 \%$ (data not shown); variation that was even higher after a $72 \mathrm{~h}$ treatment (Fig. $2 \mathrm{~A})$. This process was also common to drugs other than MTAs since 50nM doxorubicine (IC70) also triggered a decrease in Bcl-2 protein level by $51 \%$ and $39 \%$ at $48 \mathrm{~h}$ and $72 \mathrm{~h}$ respectively in A549 cells (data not shown).

\subsection{VRL down-regulates Bcl-2 at a transcriptional level}

We then determined whether the decrease of Bcl-2 protein was exclusively due to its degradation, or whether it was accompanied with a decrease in Bcl-2 mRNA levels. Quantitative RT-PCR analyses of the Bcl-2 mRNA expression in untreated and VRL-treated A549 cells were performed. Results showed a $60 \pm 7 \%$ and $70 \pm 5 \%$ decrease $(p<0.05)$ in Bcl2 mRNA with 10 and $100 \mathrm{nM}$ respectively, early as $24 \mathrm{~h}$ (Fig. 2B). The Bcl-2 mRNA decrease persisted after a $48 \mathrm{~h}$ of VRL treatment ( $68 \pm 10 \%$ for $100 \mathrm{nM}$ VRL for example). 
Bcl-2 mRNA levels were also lower $(79 \pm 18 \%)$ in A549 cells treated with 50nM doxorubicine for $24 \mathrm{~h}$ (data not shown).

In VRL-treated MCF7 cells, similar results were found from 24h (37\% decrease with 5nM, data not shown).to 48h (Fig. 2B). On the opposite, in another breast cancer cell line SKBR3, we did not found any variation in Bcl-2 mRNA level, either at 24h (data not shown) or at $48 \mathrm{~h}$ (Fig. 2B).

We then evaluated Bcl-2 transcription activation by gauging Bcl-2 heterogeneous nuclear RNA (hnRNA) levels by RT-PCR analysis (Fig. 3A). hnRNAs are the first products of transcription that contain both introns and exons. VRL induced a significant decrease in Bcl-2 hnRNA level in A549 cells, with a maximal impact at $8 \mathrm{~h}$ post-treatment with both $10 \mathrm{nM}$ (50 $\pm 19 \%)$ and $100 \mathrm{nM}$ VRL $(70 \pm 8 \%)$. This change in hnRNA cellular content was still measured at $12 \mathrm{~h}$ post-VRL treatment (data not shown). All these data highlighted an early transcriptional regulation of the Bcl-2 gene.

To definitely confirm this process, we transfected the Bcl-2 full length promoter luciferase construct in A549 cells and evaluated promoter activity by comparing luciferase activity in VRL treated and untreated cells. As shown in Fig. 3B, Bcl-2 promoter activity was inhibited by $100 \mathrm{nM}$ VRL as early as $4 \mathrm{~h}(30 \pm 8 \%, \mathrm{p}<0.05)$, with a higher inhibition observed at $8 \mathrm{~h}$ post-treatment $(43 \pm 5 \%)$. This significant decrease was also found after $8 \mathrm{~h}$ treatment with

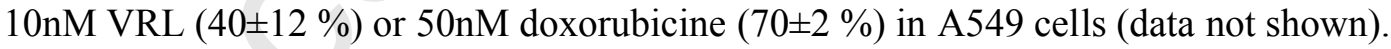
Moreover, in agreement with mRNA quantification, bcl-2 promoter activity was decreased at 8h by 5 and 50nM VRL in MCF7 cells, while it remained significantly unchanged in SKBR3 cells (Fig. 3B).

Taken together, our results indicated that Bcl-2 down-regulation during tumour cell apoptosis involves an inhibition of the Bcl-2 promoter activity. 


\subsection{Vinorelbine-mediated increase in p53 expression is responsible for Bcl-2 down- regulation and apoptosis}

Since the transcriptional regulation of Bcl-2 specifically occurred in A549 and MCF7 cells, which express wild-type p53, and was not observed in the p53 mutated SKBR3 cells, we hypothesised that p53 may be involved in Bcl-2 down-regulation. Thus we first measured p53 expression level in VRL-treated cells (48h). As shown in Fig. 4, 10nM VRL induced a high increase (14 \pm 4 fold) in this transcription factor in A549 cells. This induction was associated with an increase in p21 expression level (32 fold), well- known target of p53. One can observe that higher concentrations of VRL were less effective than 10nM, even if p53 and p21 remained largely induced ( $10 \pm 2$ fold for p53 and 26 fold for p21 at $100 \mathrm{nM})$. While microtubule-governed p53 transport is enhanced by low MTA concentrations, the high concentrations may disturb p53 nuclear translocation, as previously proposed [20, 40].

Then, to determine whether p53 could be involved in Bcl-2 down-regulation, we used the specific p53 inhibitor pifithrin $\alpha(30 \mu \mathrm{M})$. Pifithrin $\alpha$ is able to inhibit p53-dependent apoptosis by reversible inhibition of both p53 transactivation activity and p53 downstream events [26]. We verified the effect of this specific inhibitor by studying $\mathrm{p} 53$ and $\mathrm{p} 21$ protein expression levels in VRL-treated and untreated A549 cells. As shown in Fig. 5A, pifithrin $\alpha$ treatment prevented VRL-induced p53 and p21 increases. More interestingly, VRL-mediated Bcl-2 down-regulation was also inhibited by pifithrin $\alpha$, supporting the link between p53 activity and $\mathrm{Bcl}-2$ transcriptional regulation.

Furthermore, we studied apoptosis in A549 cells simultaneously treated with pifithrin $\alpha$ and VRL (72h) and showed that inhibition of p53 activity decreased the number of fragmented nuclei containing cells (Fig. 5B). Indeed, 100nM VRL induced $27 \pm 4 \%$ of apoptotic cells while apoptosis was reduced to $13 \pm 5 \%$ when VRL was combined with 
pifithrin $\alpha(\mathrm{p}<0.05)$. Altogether, our results indicate that p53 is likely responsible for the transcriptional regulation of $\mathrm{Bcl}-2$, and thus participates to apoptosis triggering.

\subsection{Identification of a novel $\mathbf{p 5 3}$ binding site on Bcl-2 promoter}

To determine the in vivo interaction between p53 protein and its potential binding site on Bcl-2 promoter, chromatin immunoprecipitation (ChIP) assays with a $\mathrm{p} 53$-specific antibody were performed. We first confirmed the increased binding of p53 at the responsive element (RE) site and the Sp1 site in p21WAF1 promoter reported by Habold et al. [27] after VRL treatment (data not shown). Using bioinformatics approach, we identified one p53 consensus binding site $1 \mathrm{~kb}$ upstream of $\mathrm{Bcl} 2 \mathrm{P}_{1}$ promoter TSS (Fig.6A). Moreover, ChIP revealed that $\mathrm{p} 53$ association to $\mathrm{Bc1} 2$ promoter was stimulated by VRL treatment (Fig.6B). However, no significant increase of $\mathrm{p} 53$ binding to $\mathrm{P}_{2}$ promoter TATA box during VRL treatment was found in contrast to previous report [16]. Thus, our data revealed a novel p53 binding site which appeared as major in our VRL-induced apoptosis induction. 


\section{Discussion}

Understanding and unravelling mechanisms of anticancer drug-induced apoptosis is of prime importance, not only for designing effective therapeutic interventions and developing novel cancer therapy strategies, but also for monitoring cancer responses to chemotherapeutic drugs. With better knowledge, it should be possible to implement a more rational usage of chemotherapeutic agents specifically for certain tumour types. Indeed, in the cellular response to genotoxic stresses generated by various anticancer agents, cell cycle checkpoint and apoptosis are considered to be two of the major biological events in maintaining genomic stability. Vinca alkaloid cytotoxicity is well-documented and strongly related to apoptosis induction $[7,8,28]$.

To provide deeper insight into the mechanisms underlying induction of apoptosis following VRL treatment in A549 cells, we investigated the involvement of the antiapoptotic protein Bcl-2. Actually, Bcl-2 inactivation may lead to the apoptotic process enabling activation of the caspases and, consequently, the degradation of structural proteins such as PARP [29]. As described with taxanes [30], the present study showed that Bcl-2 is downregulated following VRL treatment. This frequently observed Bcl-2 decrease at protein level is often associated with phosphorylation-mediated Bcl-2 inactivation and degradation [31, 32]. In our conditions, this decrease in Bcl-2 protein levels was correlated to a lower intracellular amount of Bcl-2 mRNA. Other authors have reported that paclitaxel treatment reduced Bcl-2 mRNA [33-34] and suggested that it was due to post-transcriptional mechanisms as mRNA destabilisation rather than decreased transcription. In our study, we found that VRL acts on Bcl-2 expression at a transcriptional level, by decreasing the promoter activity. Thus, VRL-induced Bcl-2 down-regulation probably occurs through a combination of two phenomena, i.e. protein degradation and mRNA regulation. It should be noticed that the decrease in Bcl-2 promoter activity has also been described with other drugs than those 
targeting microtubules, including 5FU and Carboplatin [35]. We confirmed in the present work that Bcl-2 mRNA decrease following its promoter down-regulation is not MTA specific since this process also occurs after doxorubicine treatment. The Bcl-2 promoter contains binding sites for several transcription factors and is regulated by a complex protein network. There is a possibility that each treatment would involve a specific protein connection which could disturb Bcl-2 transcription.

It is well-known that p53 expression is induced by different anti-cancer drugs, including MTAs [6-7]. Consistently with this and our previous data [20], the present study showed that VRL increased the amount of cellular p53 and its target gene p21 that reflects p53 functionality. p53 has been shown to display a direct effect on apoptosis. Especially, p53 mediates apoptosis by transactivating genes that enhance apoptosis, such as Bax [36], and by repressing genes that inhibit apoptosis, such as Bcl-2 [37]. The negative regulation of Bcl-2 by $\mathrm{p} 53$ has been shown by transient transfection of wild-type p53 that repressed the Bcl-2 full-length promoter [38]. Moreover, the relationship between drug-induced apoptosis, p53 and Bcl-2 gene expression has been previously demonstrated in vitro [39] and some authors have confirmed that the down-regulation of Bcl-2 and/or the up-regulation of p53 and p21 are certainly one of the important modes of apoptosis induction by taxanes [30]. Our data obtained after pifithrin $\alpha$ incubation support the notion that VRL treatment triggers p53 activation and leads to a p53-dependent down-regulation of Bcl-2. This link is reinforced by comparative studies of the p53 wild-type (A549 and MCF7) and inactive (SKBR3) cancer cell lines, since a functional p53 protein appeared to be necessary for Bcl-2 transcriptional regulation by VRL. Then, the anticancer drug-induced Bcl-2 down-regulation rather depends on the p53 status than on the cellular type of tumour.

ChIP assays further confirmed p53 role, showing that VRL increased p53 interaction with $\mathrm{Bcl}-2$ promoter, in a novel region located in the $\mathrm{P}_{1}$ promoter. It should however be 
noticed that we did not measure a significant binding of p53 on the TATA box, in contrast to what has been recently described [16]. This discrepancy in the results could be due to the techniques used, since Bredow et al. did not evaluate p53 interaction with the endogenous gene, but only with bcl-2 promoter luciferase contructs.

As Bcl-2 promoter contains many binding sites for different transcription factors, one could assume that several regulation proteins may be implicated in the VRL-induced Bcl-2 decrease. For example, the transcription factor NF- $\mathrm{BB}$ has also been suggested to play a role in the down-regulation of Bcl-2 gene expression during treatment with anticancer drugs like 5FU and Carboplatin [41]. Its inhibition by such treatments results in down-regulation of the Bcl-2 promoter. We cannot therefore rule out the possibility that transcription factors other than p53 may also be involved in Bcl-2 down-regulation.

Lastly, the involvement of microtubules in signal transduction and the relationship between microtubules and transcription factors is becoming an intensive research area. As an increasing number of proteins with crucial intracellular functions are shown to traffic via microtubules, the significance of interfering with this microtubule function will take on increasing importance. Activation of transcription factors that target downstream genes, including apoptosis-related genes, play a critical role in promoting anticancer drug activity. Therefore, a better understanding of the molecular effects of MTA-based treatments would help to improve the efficacy of the related chemotherapy.

In conclusion, our study provides further insight into the molecular mechanism underlying VRL-induced apoptosis of cancer cells, by showing a transcriptional decrease in Bcl-2. Furthermore, we highlight the pivotal role of p53 in VRL-induced apoptosis and open up possibilities for improving MTA efficiency, such as adapting treatment according to p53 status and Bcl-2 tumour profile expression. Given the strong relationship between apoptosis and drug effectiveness, reinforcement of p53 activity and/or abrogation of Bcl-2 expression 
could represent attractive ways to promote MTA-induced apoptosis and enhance cell sensitivity to this kind of treatment.

\section{Acknowledgments:}

The authors thank Dr Richard J Bold (Division of Surgical Oncology, Sacramento, USA) for the Bcl-2 promoter/luciferase construct and Alain Desobry for his technical assistance.

\section{Footnotes}

This research was partially supported by INCa and Cancéropole PACA (France). 


\section{References}

[1] Reed JC. Mechanisms of apoptosis. Am J Pathol 2000;157:1415-30.

[2] Borner C. The Bcl-2 protein family: sensors and checkpoints for life-or-death decisions. Mol Immunol 2003;39:615-47.

[3] Kirkin V, Joos S. The role of Bcl-2 family members in tumorigenesis. Biochim Biophys Acta 2004;1644:229-49.

[4] Bao Q, Shi Y. Apoptosome: a platform for the activation of initiator caspases. Cell Death Differ 2007; 14:56-65.

[5] Aapro MS, Harper P, SA J, Vermorken JB. Developments in cytotoxic chemotherapy: advances in treatment utilising vinorelbine. Crit Rev Oncol Hematol 2001;40:251-63.

[6] Khawaja NR, Carré M, Kovacic H, Estève MA, D. B. Patupilone-induced apoptosis is mediated by mitochondrial reactive oxygen species through Bim relocalization to mitochondria. Mol Pharmacol 2008;74:1072-83.

[7] Bressin C, Bourgarel-Rey V, Carré M, Pourroy B, Arango D, Braguer D, et al. Decrease in c-Myc activity enhances cancer cell sensitivity to vinblastine. Anticancer Drugs 2006;17:181-7.

[8] Estève MA, Carré M, D. B. Microtubules in apoptosis induction: are they necessary? Curr Cancer Drug Targets 2007;7:713-29.

[9] Seto M, Jaeger U, Hockett RD, Graninger W, S B, Goldman P. Alternative promoters and exons, somatic mutation and deregulation of the Bcl-2-Ig fusion gene in lymphoma. EMBO J 1988;7:123-31.

[10] Wilson BE, Mochon E, Boxer LM. Induction of bcl-2 expression by phosphorylated CREB proteins during B-cell activation and rescue from apoptosis. Mol Cell Biol 1996;16:5546-56.

[11] Heckman CA, JW M, Boxer LM. NF-kappaB activates Bcl-2 expression in $\mathrm{t}(14 ; 18)$ lymphoma cells. Oncogene 2002;21:3898-908.

[12] Chen HM, Boxer LM. Pi 1 binding sites are negative regulators of bcl-2 expression in pre-B cells. Mol Cell Biol 1995;15:3840-7.

[13] Heckman C, Mochon E, Arcinas M, Boxer LM. The WT1 protein is a negative regulator of the normal bcl-2 allele in $\mathrm{t}(14 ; 18)$ lymphomas. J Biol Chem 1997;272:19609-14 
[14] Miyashita T, Harigai M, Hanada M, Reed JC. Identification of a p53-dependent negative response element in the bcl-2 gene. Cancer Res 1994;54:3131-5.

[15] Wu Y, Mehew JW, Heckman CA, Arcinas M, Boxer LM. Negative regulation of bcl-2 expression by p53 in hematopoietic cells. Oncogene 2001;20:240-51.

[16] Bredow S, Juri DE, Cardon K, Tesfaigzi Y. Identification of a novel Bcl-2 promoter region that counteracts in a p53-dependent manner the inhibitory $\mathrm{P} 2$ region. Gene 2007;404:110-6.

[17] Breitschopf K, Haendeler J, Malchow P, AM Z, Dimmeler S. Posttranslational modification of Bcl-2 facilitates its proteasome-dependent degradation: molecular characterization of the involved signaling pathway. Mol Cell Biol 2000;20:1886-96.

[18] George J, Banik NL, Ray SK. Bcl-2 siRNA augments taxol mediated apoptotic death in human glioblastoma U138MG and U251MG cells. Neurochem Res 2009;34:66-78.

[19] Zhu BK, Wang P, Zhang XD, Jiang CC, Chen LH, Avery-Kiejda KA, et al. Activation of Jun N-terminal kinase is a mediator of vincristine-induced apoptosis of melanoma cells. Anticancer Drugs 2008;19:189-200.

[20] Pourroy B, Carré M, Honoré S, Bourgarel-Rey V, Kruczynski A, Briand C, et al. Low concentrations of vinflunine induce apoptosis in human SK-N-SH neuroblastoma cells through a postmitotic G1 arrest and a mitochondrial pathway. Mol Pharmacol 2004;66:580-91.

[21] Pasquier E, Carré M, Pourroy B, Camoin L, Rebaï O, Briand C, et al. Antiangiogenic activity of paclitaxel is associated with its cytostatic effect, mediated by the initiation but not completion of a mitochondrial apoptotic signaling pathway. Mol Cancer Ther 2004;3:1301-10.

[22] Ferlini C, Raspaglio G, Mozzetti S, Distefano M, Filippetti F, Martinelli E, et al. Bcl-2 down-regulation is a novel mechanism of paclitaxel resistance. Mol Pharmacol 2003;64:51-8.

[23] Estève MA, Carré M, Bourgarel-Rey V, Kruczynski A, Raspaglio G, Ferlini C, et al. Bcl-2 down-regulation and tubulin subtype composition are involved in resistance of ovarian cancer cells to vinflunine. Mol Cancer Ther 2006;5:2824-33.

[24] Garcia P, Braguer D, Carles G, el Khyari S, Barra Y, de Ines C, et al. Comparative effects of taxol and Taxotere on two different human carcinoma cell lines. Cancer Chemother Pharmacol 1994;34:335-43. 
[25] Fahy BN, Schlieman M, Virudachalam S, Bold RJ. AKT inhibition is associated with chemosensitisation in the pancreatic cancer cell line MIA-PaCa-2. Br J Cancer 2003;89:391-7.

[26] Komarov PG, Komarova EA, Kondratov RV, Christov-Tselkov K, Coon JS, Chernov $\mathrm{MV}$, et al. A chemical inhibitor of $\mathrm{p} 53$ that protects mice from the side effects of cancer therapy. Science 1999;285:1733-7.

[27] Habold C, Poehlmann A, Bajbouj K, Hartig R, Korkmaz KS, Roessner A, et al. Trichostatin A causes p53 to switch oxidative-damaged colorectal cancer cells from cell cycle arrest into apoptosis. J Cell Mol Med 2008;12:607-21.

[28] Jordan MA. Mechanism of action of antitumor drugs that interact with microtubules and tubulin. Curr Med Chem Anticancer Agents 2002;2:1-17.

[29] Allen RT, Cluck MW, Agrawal DK. Mechanisms controlling cellular suicide: role of Bcl-2 and caspases. Cell Mol Life Sci 1998;54:427-45.

[30] Ganansia-Leymarie V, Bischoff P, Bergerat JP, Holl V. Signal transduction pathways of taxanes-induced apoptosis. Curr Med Chem Anticancer Agents 2003;3:291-306.

[31] Haldar S, Jena N, Croce CM. Inactivation of Bcl-2 by phosphorylation. Proc Natl Acad Sci U S A 1995;92:4507-11.

[32] Mc Gee MM, Greene LM, Ledwidge S, Campiani G, Nacci V, Lawler M, et al. Selective induction of apoptosis by the pyrrolo-1,5-benzoxazepine 7[[dimethylcarbamoyl]oxy]-6-(2-naphthyl)pyrrolo-[2,1-d] (1,5)-benzoxazepine (PBOX-6) in Leukemia cells occurs via the c-Jun NH2-terminal kinase-dependent phosphorylation and inactivation of Bcl-2 and Bcl-XL. J Pharmacol Exp Ther 2004;310 1084-95.

[33] Tudor G, Aguilera A, Halverson DO, Laing ND, Sausville EA. Susceptibility to druginduced apoptosis correlates with differential modulation of Bad, Bcl-2 and Bcl-xL protein levels. Cell Death Differ 2000;7:574-86.

[34] Bandyopadhyay S, Sengupta TK, Fernandes DJ, Spicer EK. Taxol- and okadaic acidinduced destabilization of bcl-2 mRNA is associated with decreased binding of proteins to a bcl-2 instability element. Biochem Pharmacol 2003;66:1151-62.

[35] Singh S, Chhipa RR, Vijayakumar MV, Bhat MK. DNA damaging drugs-induced down-regulation of Bcl-2 is essential for induction of apoptosis in high-risk HPVpositive HEp-2 and KB cells. Cancer Lett 2006;236:213-21.

[36] Miyashita T, Reed JC. Tumor suppressor p53 is a direct transcriptional activator of the human bax gene. Cell 1995;80:293-9. 
[37] Miyashita T, Krajewski S, Krajewska M, Wang HG, Lin HK, Liebermann DA, et al. Tumor suppressor p53 is a regulator of bcl-2 and bax gene expression in vitro and in vivo. Oncogene 1994;9:1799-805.

[38] Wu Y, Mehew JW, Heckman CA, Arcinas M, Boxer LM. Negative regulation of Bcl2 expression by p53 in hematopoietic cells. Oncogene 2001;20:240-51.

[39] Suzuki K, Kazui T, Yoshida M, Uno T, Kobayashi T, Kimura T, et al. Drug-induced apoptosis and p53, BCL-2 and BAX expression in breast cancer tissues in vivo and in fibroblast cells in vitro. Jpn J Clin Oncol 1999;29:323-31.

[40] Giannakakou P, Nakano M, Nicolaou KC, O'Brate A, Yu J, Blagosklonny MV, et al. Enhanced microtubule-dependent trafficking and p53 nuclear accumulation by suppression of microtubule dynamics. Proc Natl Acad Sci U S A 2002;99:10855-60.

[41] Singh S, Bhat MK. Carboplatin induces apoptotic cell death through downregulation of constitutively active nuclear factor-kappaB in human HPV-18 E6-positive HEp-2 cells. Biochem Biophys Res Commun 2004;318:346-53. 


\section{Figure legends}

Fig. 1 - Vinorelbine induces apoptosis in A549 cells.

(A) Concentration-dependent inhibition of cell survival after a $72 \mathrm{~h}$ treatment by VRL using MTT assay.

(B) DAPI staining of cells visualized by fluorescent microscopy (magnification X40). Apoptotic cells contain fragmented nuclei (see arrow). Cells were incubated with $0 \mathrm{nM}$ (control), 10, 50 and $100 \mathrm{nM}$ VRL over $72 \mathrm{~h}$. The graph shows percentages of apoptotic cells $(* \mathrm{p}<0.05)$

(C) Immunoblotting analysis of PARP cleavage from $116 \mathrm{kDa}$ to $89 \mathrm{kDa}$. A549 cells were incubated with $0 \mathrm{nM}$ (control), $10 \mathrm{nM}$ or $50 \mathrm{nM}$ VRL over $48 \mathrm{~h}$. Actin immunoblot serves as loading control.

Fig. 2 - Bcl-2 expression is downregulated in VRL-treated cells.

(A): Bcl-2 protein expression was assessed by Western blotting after $48 \mathrm{~h}$ and $72 \mathrm{~h}$ of treatment in the A549 and MCF7 cells. Actin immunoblot serves as loading control.

(B): Bcl-2 mRNA expression was analyzed by quantitative RT-PCR.

A549, MCF7 and SKBR3 cells were treated for $24 \mathrm{~h}$ or $48 \mathrm{~h}$ with different doses of VRL. The RelQuant software adjusts the Bcl-2 expression to $\beta 2 \mathrm{~m}$ expression values. The results are expressed as means and SD of five independent experiments $(* \mathrm{p}<0.05)$.

Fig. 3 - Bcl-2 transcription activation is decreased by VRL treatment.

(A): Bcl-2 hnRNA levels were assessed by RT-PCR analysis. Cells were treated for $8 \mathrm{~h}$ with $0 \mathrm{nM}$ (control), $10 \mathrm{nM}$ or $100 \mathrm{nM}$ VRL. Agarose gel electrophoresis band intensity was estimated using densitometric measurements. The REL (relative expression level) equals the 
densitometric value of Bcl-2/the densitometric value of $\beta 2 \mathrm{~m}$. The graph shows means and SD of five independent experiments $(* \mathrm{p}<0.05)$.

(B): Effect of VRL on luciferase activity in A549, MCF7 and SKBR3 cells. Cells were transfected by pGL3-bcl2 and stimulated with different doses of VRL during 4 and $8 \mathrm{~h}$ in A549 cells, and 8h in MCF7 and SKBR3 cells. The results are expressed as means and SD of three independent experiments, with each condition tested in triplicate.

Fig. 4 - VRL treatment increases p53 and p21 levels in A549 cells. p53 and p21 levels were assessed in the A549 cells by Western blotting after a $48 \mathrm{~h}$ treatment with $0 \mathrm{nM}$ (control), $10 \mathrm{nM}, 50 \mathrm{nM}$ or $100 \mathrm{nM}$ VRL. Actin immunoblot serves as loading control.

Fig. 5 - Pifithrin $\alpha$ prevents p53, p21 and Bcl-2 VRL-induced modulations and apoptosis. A- p53, p21 and Bcl-2 levels were measured in the A549 cells after a 48 h treatment with 10 nM VRL with or without $30 \mu \mathrm{M}$ of pifithrin $\alpha$. Actin immunoblot serves as loading control. B- DAPI staining of cells visualized by fluorescent microscopy (magnification X40). A549 cells were incubated for $72 \mathrm{~h}$ with $0 \mathrm{nM}$ (control), and $100 \mathrm{nM}$ VRL. The photographs are representative of the four different conditions, i.e. untreated cells, $100 \mathrm{nM}$ VRL, $30 \mu \mathrm{M}$ pifithrin $\alpha$ and co-treatment with $100 \mathrm{nM}$ VRL and $30 \mu \mathrm{M}$ pifithrin $\alpha$. The graph represents the percentage of apoptotic cells after $72 \mathrm{~h}$ VRL treatment with 50 or $100 \mathrm{nM}(* \mathrm{p}<0.05)$.

Fig. 6- Identification of a novel binding site of $\mathrm{p} 53$ on the Bcl-2 promoter A- Schematic diagram of the human Bcl-2 promoter. $\mathrm{P}_{1}$ and $\mathrm{P}_{2}$ are located at -1431 bp and $58 \mathrm{bp}$ relative to the initial ATG. $\mathrm{P}_{1}$ TTS (P1 transcriptional start site) is located at $-714 \mathrm{bp}$ 
(NM_000633). PNRE (p53 negative responsive element) was indicated as described by Miyashita et al., 1994.

B-Fixation of p53 on Bcl-2 promoter was measured by ChIP assay coupled to detection by qRT-PCR. We evaluated the binding of p53 protein on the identified p53 site and on the TATA sequence in A549 cells treated or not by 10nM of VRL. The fold enrichment of the immunoprecipitation was calculated by dividing the quantities of DNA in the anti-p53precipitated samples by that of the matched control antibody $(\operatorname{IgG} 2 a)\left({ }^{* *} p<0.005\right)$. 


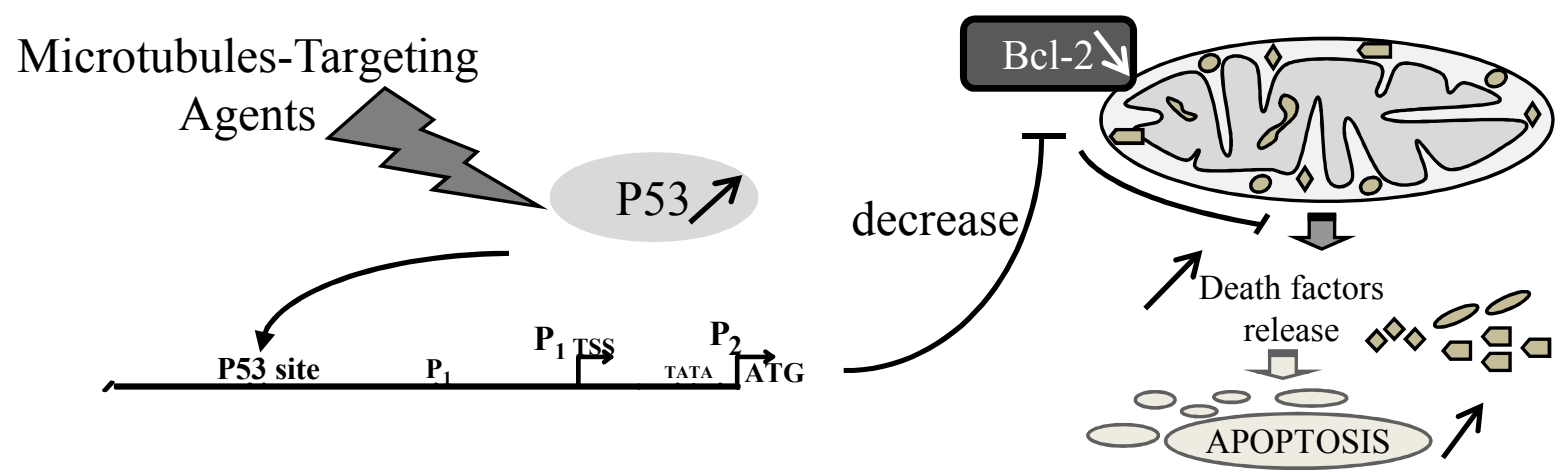


Table 1 Sequences of primers

\begin{tabular}{|c|c|c|}
\hline Gene & & Sequence \\
\hline Bcl-2 & $\begin{array}{l}\text { Real-time } \\
\text { RT-PCR }\end{array}$ & $\begin{array}{l}\text { F: 5' GGTGAACTGGGGGAGGATTGT 3', } \\
\text { R : 5' CTTCAGAGACAGCCAGGAGAA 3', }\end{array}$ \\
\hline$\beta 2$-microglobulin & $\begin{array}{l}\text { Real-time } \\
\text { RT-PCR }\end{array}$ & $\begin{array}{l}\text { F : 5' CCGACATTGAAGTTGACTTAC 3' } \\
\text { R: 5' ATCTTCAAACCTCCATGATG 3' }\end{array}$ \\
\hline hnRNA Bcl-2 & RT-PCR & $\begin{array}{l}\text { F : 5' ACCTTTCAGCATCACAGAGGA 3' } \\
\text { R : 5' CCCAGAGAAAGAAGGAGTT 3' }\end{array}$ \\
\hline $\begin{array}{l}\text { Bcl-2 promoter } \\
\text { (TATA) }\end{array}$ & ChIP & $\begin{array}{l}\mathrm{F}: 5^{\prime} \text { CAAGTGTTCCGCGTGATTG 3', } \\
\mathrm{R}: \text {, ' CCCGGTTATCGTACCCTGTT 3, }\end{array}$ \\
\hline $\begin{array}{l}\text { Bcl-2 promoter } \\
\text { (p53 site) }\end{array}$ & ChIP & $\begin{array}{l}\text { F : 5' GGTGTTAGGGACAGAGGGAAA 3' } \\
\text { R : 5' CACGTTTTAAGCAATGTCTAGGG 3' }\end{array}$ \\
\hline
\end{tabular}


Figure 1:

A

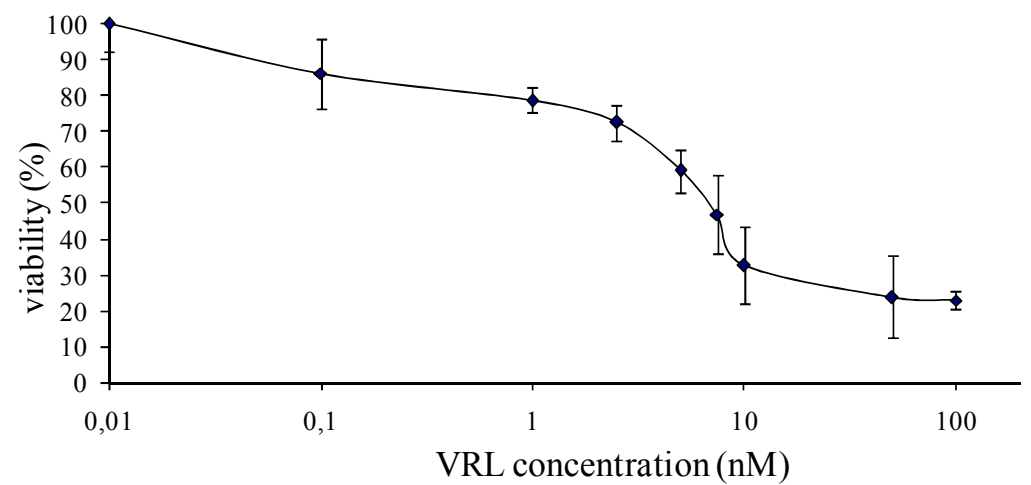

B
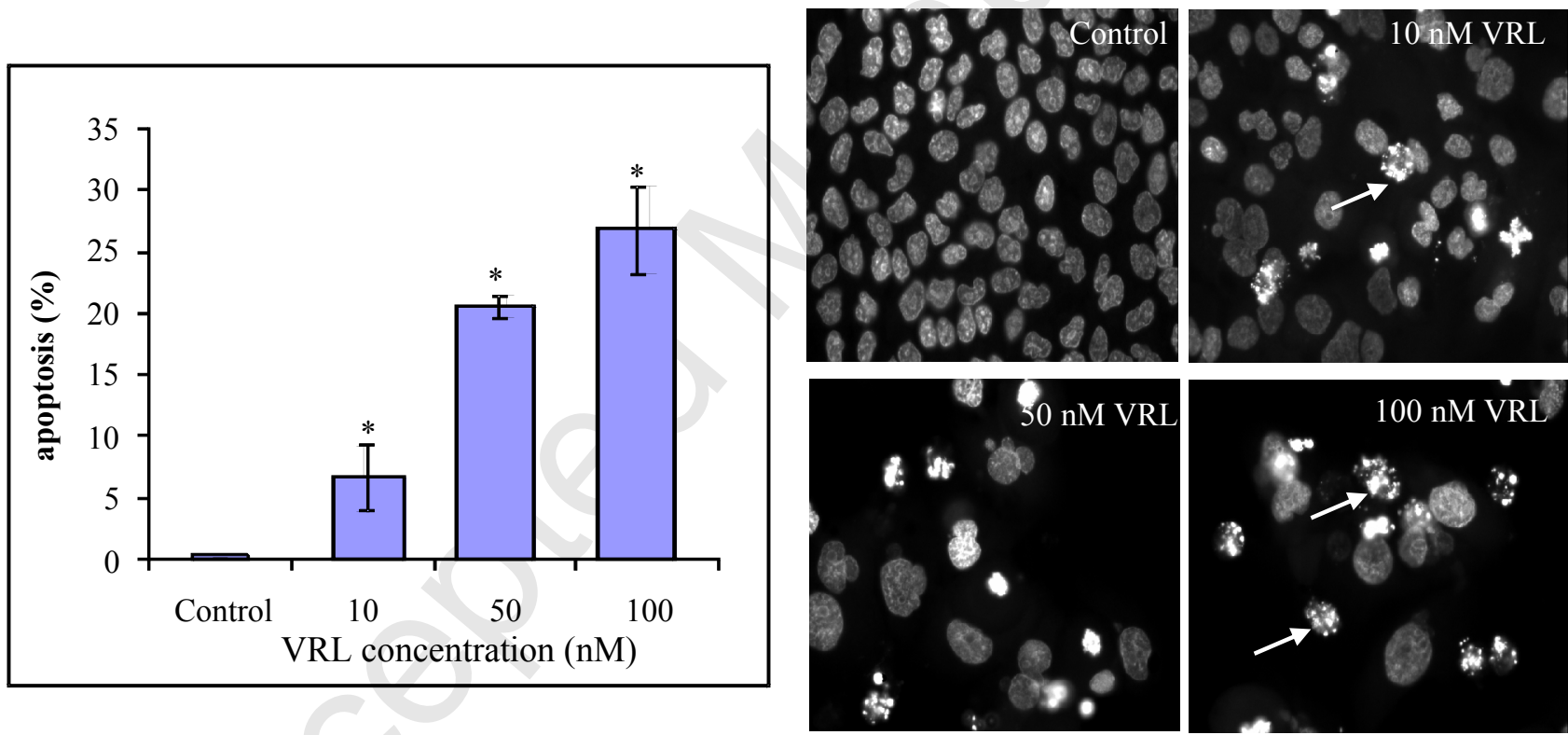

C

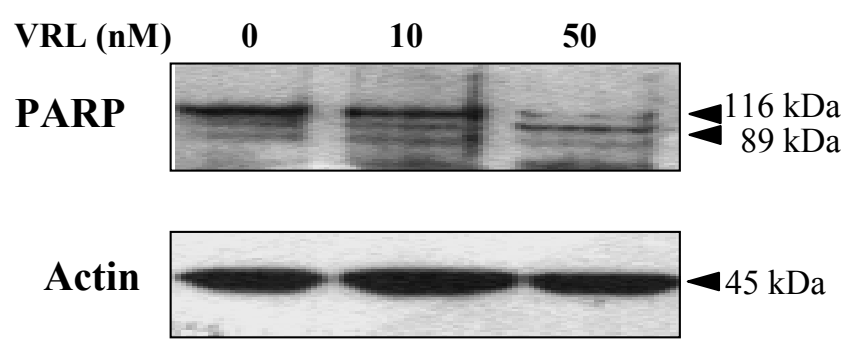


Figure 2

A

A549

MCF7
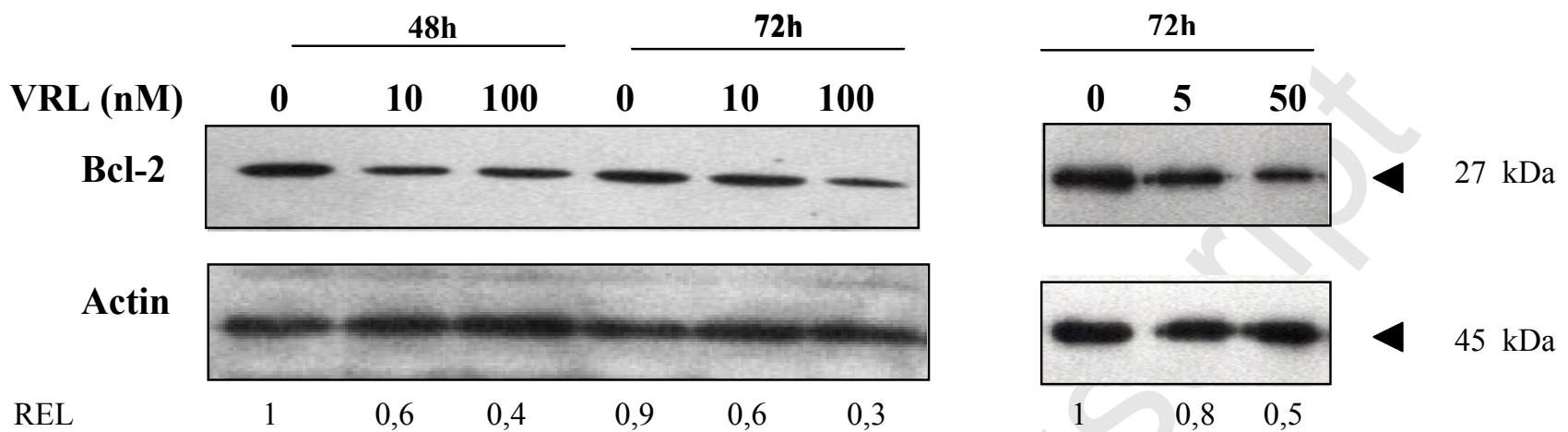

B
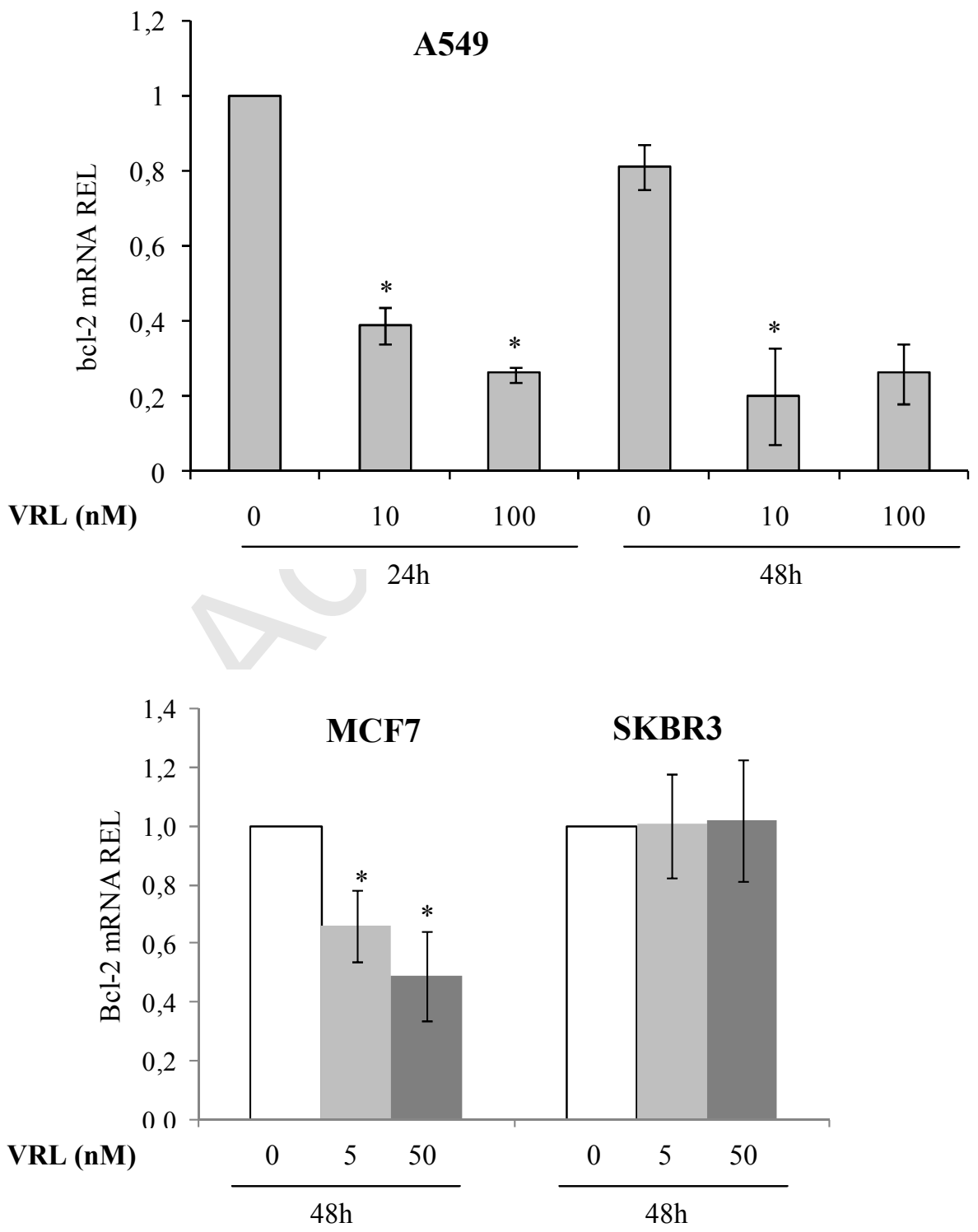
Figure 3

A

A549

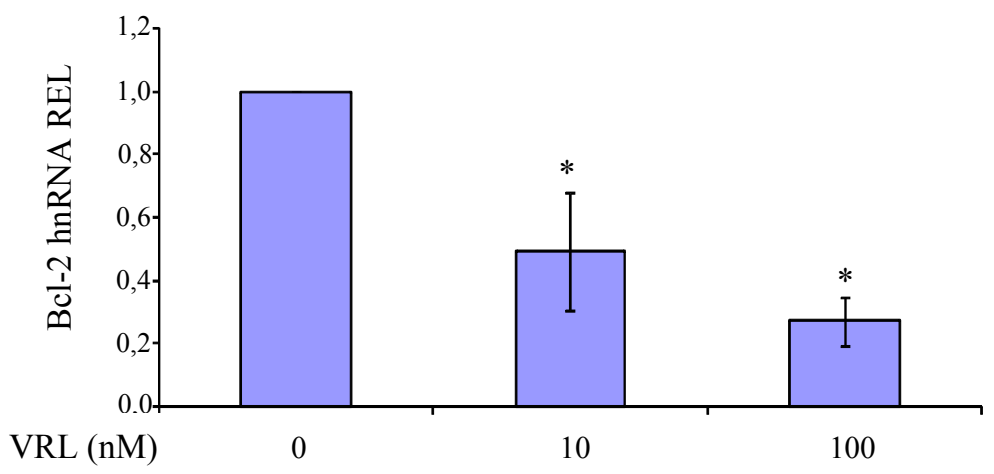

B
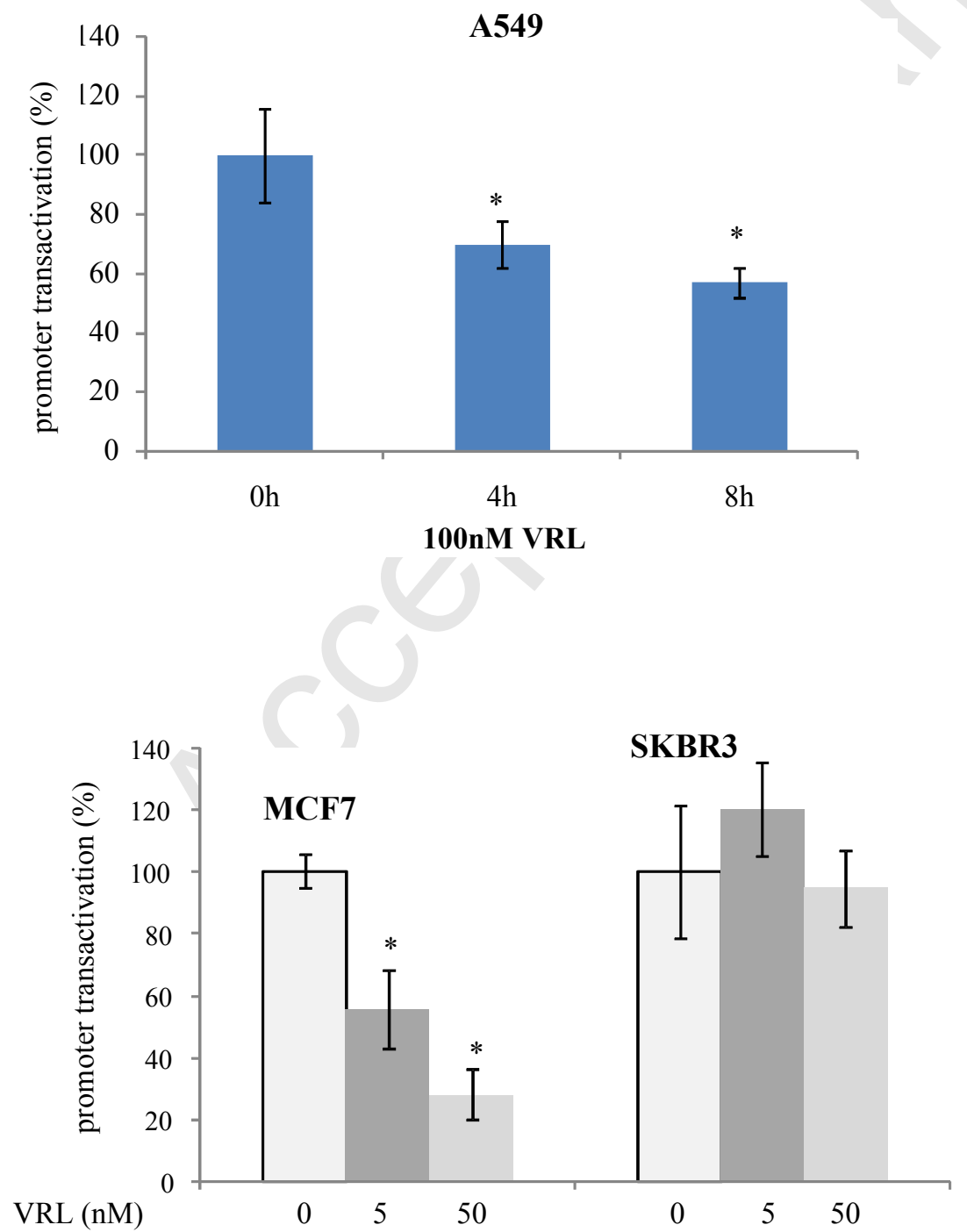
Figure 4

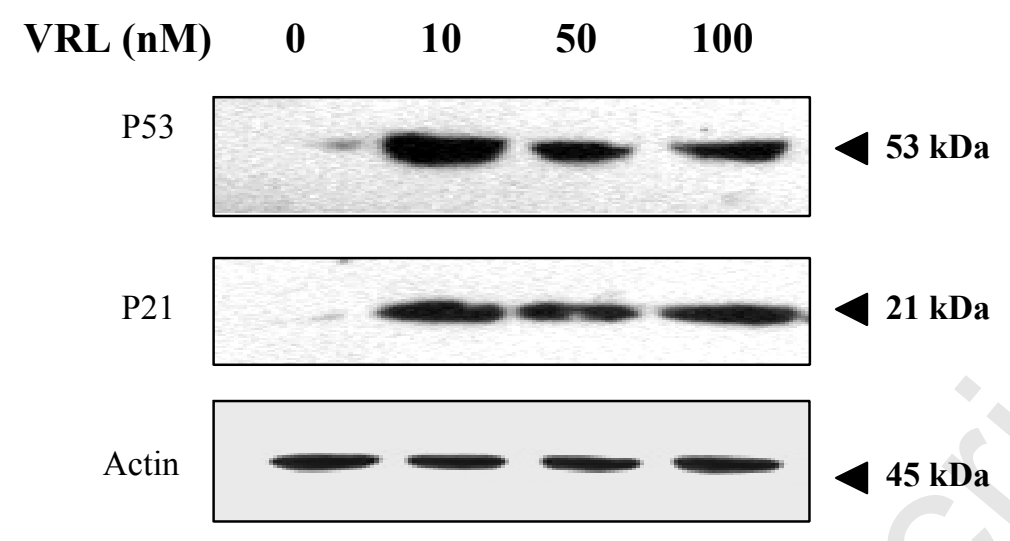




\section{Figure 5}

A

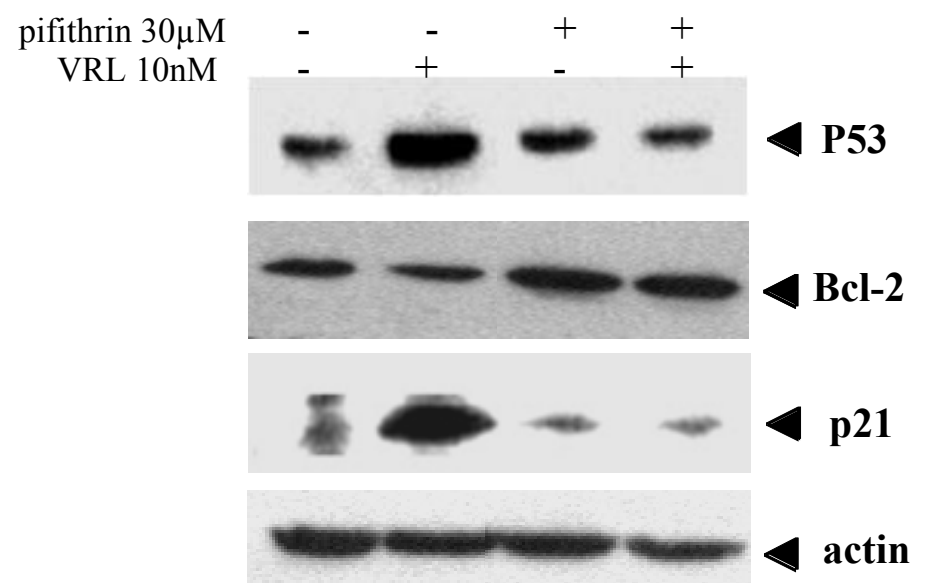

B
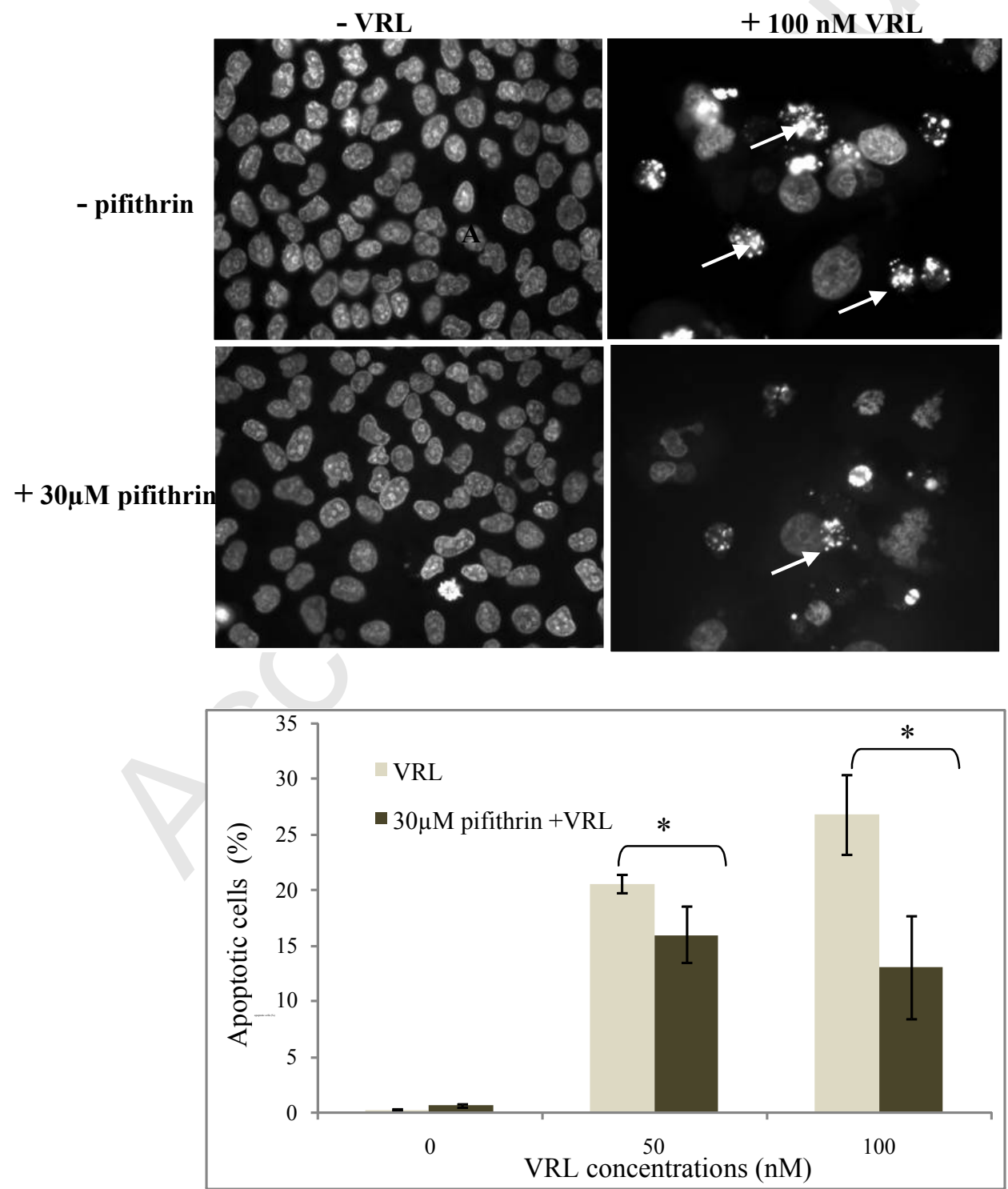
Figure 6

A

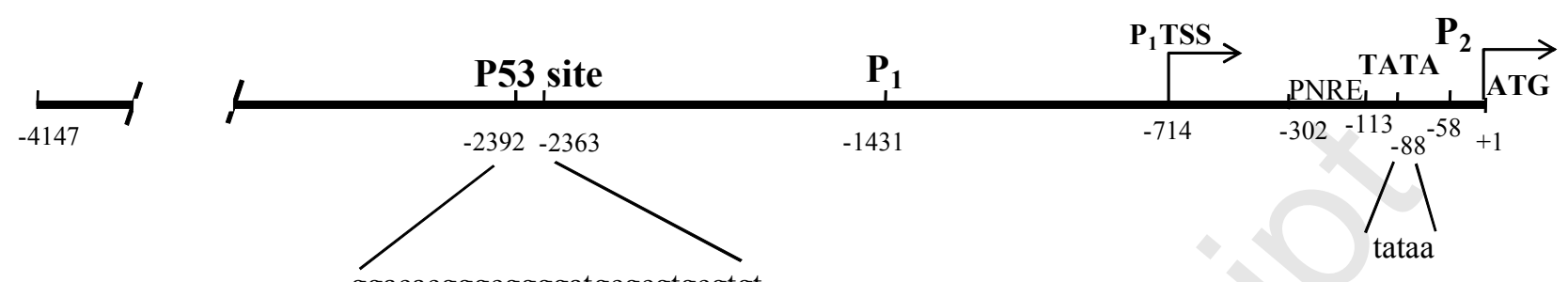

ggacacgggcggggatgcgcgtgcgtgt

B

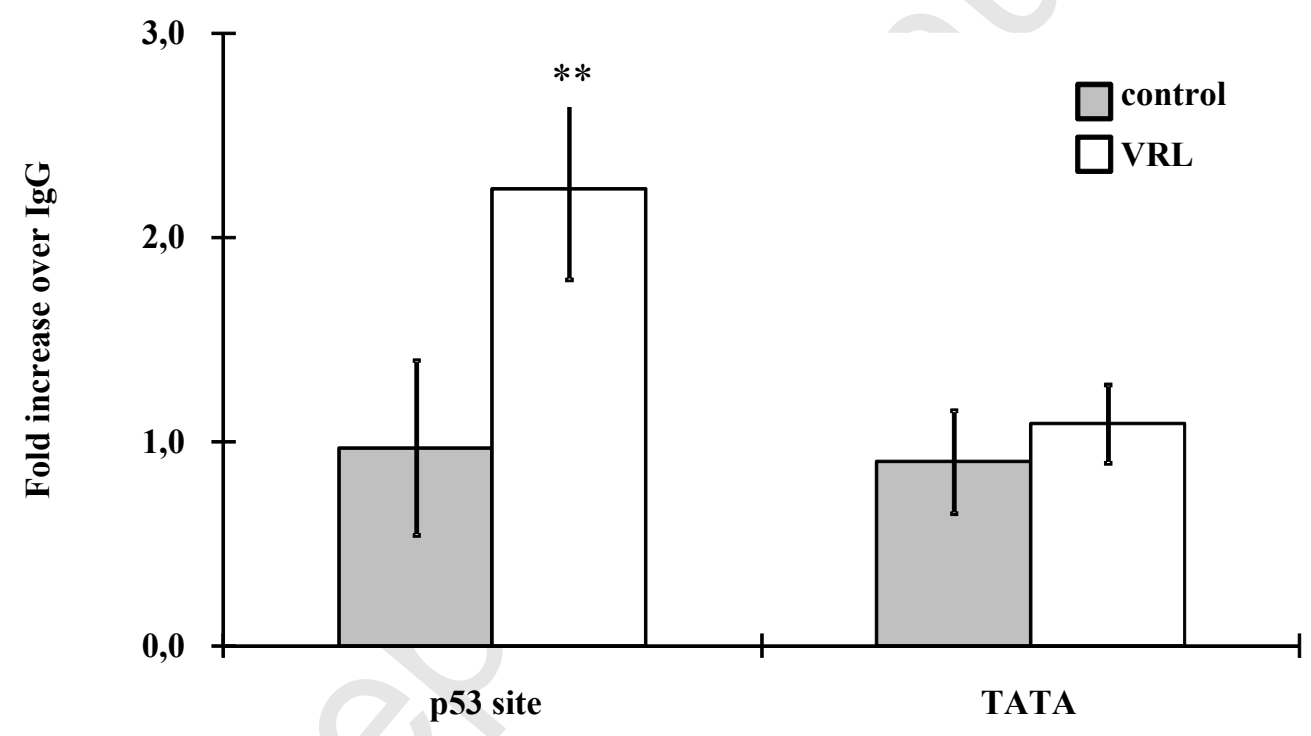

